\title{
静電微粒化法によるシリカ粒子の作製
}

\section{Production of Silica Particles by Electrostatic Atomization}

\author{
森康維, 福本 友祐 \\ Yasushige Mori, Yuusuke Fukumoto
}

\begin{abstract}
Electrostatic atomization is a typical method to produce fine liquid droplets with diameter from ten to some hundreds micrometers and a relatively narrow size distribution. This method is simple but its mechanism is not fully understood yet.

In this paper, fine silica particles were produced through dehydration and removal of sodium ions from droplets of water glass No. 3 formed by electrostatic atomization. The atomization state could be classified into three modes according to the applied voltage, that is dripping, uniform cone-jet, and discharged modes. Uniformly sized droplets were produced only under the uniform cone-jet mode at a positive high voltage. The mean volume size of silica particles could be estimated as a function of flow rate and applied voltage as well as surface tension, viscosity and conductivity of water glass solution.
\end{abstract}

Key Words : Electrostatic atomization, Silica particles, Sodium silicate solution, Uniformly sized particles, High voltage field

\section{1. 緒言}

液体から微粒子を得る方法に，まず液体を微小液滴 にし，その後乾燥操作などで溶媒を除去し，固形粒子 を得る方法がある。液体を微粒化するには，二流体， ズルやネブライザーなどの压力エネルギーを使用する 方法や，超音波噴霧法や振動オリフィス法などの機械 的振動エネルギーを加える方法が代表的である。これ に対して静電微粒化法 ${ }^{1,2)}$ は, 電気エネルギーをノズ ル先端の液体に加え, ノズルから流出する液柱を微細 液滴に分裂させる方法である。サブミクロンから数ミ リメートルまで生成液滴径を幅広く変えることがで き, しかも比較的単分散の液滴が得られるが, 処理量 の増加が見込めないのが現状である。静電微粒化法 は, 溶液の表面張力や電気的物性の影響を受け，その 特性は大きく変化することが知られている。例えば, 高導電率や高粘性係数を持つ溶液を微粒化した例は少 な( ${ }^{3)}$ 。

一方, 球形シリカ粒子を溶液から作製する方法とし て界面反応法 ${ }^{4)}$ や膜乳化法 ${ }^{5)}$ がある。界面反応法でシ

\section{0 年 9 月 29 日受付}

同志社大学工学部物質化学工学科

（干610-0321 京田辺市多々羅都谷 1-3）TEL 0774-65-6626 Department of Chemical Engineering and Materials Science, Doshisha University

(1-3 Miyakodani Tatara, Kyotanabe 610-0321)
リカ粒子を作製するには, ベンゼン中に水ガラス（ケ イ酸ナトリウム水溶液) を混合擋拌し，得られた液滴 界面で固化させる。しかしながら, 液滴生成段階のみ ならず固化段階でも液滴の合一・分裂が生じ，粒子径 分布の広い粒子が得られる。一方, 膜乳化法では, 疎 水化処理をした無機膜に水ガラスを通し, 径の揃った 液滴を作製することで球形単分散シリカを得ている が, 操作が煩雑で, $10 \mu \mathrm{m}$ 以上の粒子を得ることは 困難である。静電微粒化法でシリカ粒子を作製した例 に佐藤らの報告 ${ }^{6.7)}$ があるが, 物性の影響をあまり検 討していない。

そこで本報では, 高導電率かつ高粘性係数の水ガラ スを用いて，静電微粒化に及ぼすこれらの物性や供 給流量, 印加電圧の影響を検討し, 数百ミクロン径の 大きさの揃った球形シリ力粒子の作製条件を検討し た。

\section{2. 実験方法}

試料には, 水ガラス（水ガラス 3 号, 富士化学）と 呼ばれるケイ酸ナトリウム水溶液を用いた。水ガラス 3 号は, 珪素を $\mathrm{SiO}_{2}$ として $29 \%$ 含み, $\mathrm{SiO}_{2} / \mathrm{Na}_{2} \mathrm{O}$ のモル比が 3.2 の組成を持つ。水溶液の物性値を変 えるために水ガラスに純水を添加した。水溶液の表 面張力はウィルヘルミ一式表面張力計（協和科学, CBVP-A3), 粘性係数はコーンプレート型粘度計 
Table 1 Physical properties of sample solutions measured at $293 \mathrm{~K}$.

\begin{tabular}{ccccc}
\hline Sample No. & $\begin{array}{c}\text { Volume ratio of } \\
\text { water glass No.3 and water }\end{array}$ & $\begin{array}{c}\text { Viscosity } \\
(\mathrm{mPa} \cdot \mathrm{s})\end{array}$ & $\begin{array}{c}\text { Surface tension } \\
\left(\mathrm{mN} \mathrm{m}^{-1}\right)\end{array}$ & $\begin{array}{c}\text { Conductivity } \\
\left(\mathrm{S} \mathrm{m}^{-1}\right)\end{array}$ \\
\hline 30 & $100: 0$ & 139.3 & 71.0 & 3.46 \\
31 & $90: 10$ & 37.3 & 66.7 & 3.79 \\
32 & $80: 20$ & 21.7 & 64.0 & 3.83 \\
33 & $70: 30$ & 10.8 & 55.7 & 4.09 \\
34 & $60: 40$ & 6.7 & 52.3 & 4.11 \\
35 & $50: 50$ & 4.3 & 48.5 & 4.05 \\
\hline
\end{tabular}

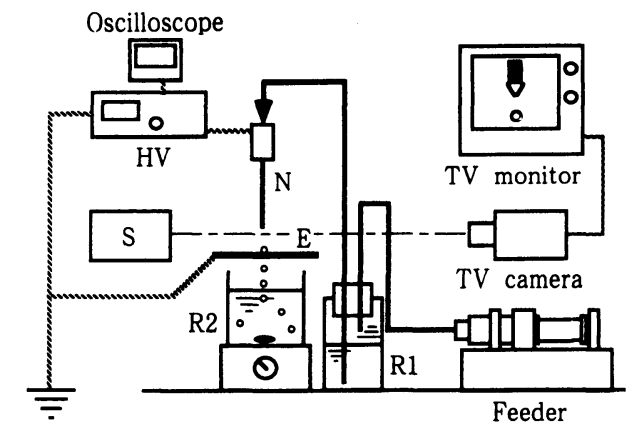

Fig. 1 Schematic diagram of experimental apparatus. $\mathrm{HV}$ : high voltage power supply, $\mathrm{N}$ : nozzle, $\mathrm{E}$ : earth electrode, $\mathrm{S}$ : stroboscope,

$\mathrm{R} 1$ : vessel with water glass and silicone oil, $\mathrm{R} 2$ : container of alcohol solution

(トキメック, $\mathrm{ED})$, 導電率は導電率計（堀場製作 所, ES-12) で測定した。Table 1 にこれらの測定値 を示す。純水の添加量を増すと, 表面張力は直線的に 減少し, 粘性係数は指数関数的に減少する。しかし導 電率は，純水を $40 \mathrm{vol} . \%$ 添加したときが最大となっ た。これは, ケイ酸ナトリウム（水ガラス）の濃度低 下とそれに伴う解離度の変化で説明できる。

Fig. 1 に実験装置の概略図を示す。液滴生成部であ るノズル $(\mathrm{N})$ には外径 $0.7 \mathrm{~mm}$, 内径 $0.4 \mathrm{~mm}$ のステ ンレス製パイプを用い, その先端を研磨し, 直角端面 に仕上げた。対向するアース電極（E）は直径 60 $\mathrm{mm}$, 厚さ $2 \mathrm{~mm}$ の真鍮製円盤で, 中心に微粒化液滴 が通過できるように直径 $10 \mathrm{~mm}$ の穴を開けた。ノズ ル先端からアース電極までの距離は $6 \mathrm{~mm}$ とした。高 電圧発生装置 (HV：松定プレシジョン, HEOPS10B2-PV）を用いて，ノズルとアース電極間に正ま たは負の直流電圧を印加した。漏電防止のため, マイ クロフィーダー（古江サイエンス，JP-S）で，シリ コンオイル（信越化学工業, KF-96-100CS）を密閉 容器（R1）に供給することで, 水ガラス溶液を R1 か らノズルへと定量的に送り出した。静電微粒化で生成
した液滴はアルコールの入ったポリエチレン容器 （R2）で受けとめ，表面を瞬間的に脱水・固化した。 微粒化の様子は TVカメラ, TV モニターおよびスト ロボスコープ（S）を用いて観察した。

アルコール中で固化した水ガラス粒子（ケイ酸ナト リウムの固体粒子）を脱ナトリウム化してシリカ粒子 にするため, アルコールと分離後, $500 \mathrm{~mol} / \mathrm{m}^{3}$ 希硫 酸水溶液に 5 分間浸漬した。このようにして作製した シリカ粒子を光学影微鏡で 200 個以上数え, 粒子径分 布を求めた。なお, 平均径には個数基準平均体積径を 用いた。

\section{3. 実験結果および考察}

\section{1 捕集溶液}

水ガラスは, 脱水・脱ナトリウム反応を経てシリカ 粒子となる。そこで, 微粒化した水ガラス液滴を直接 $500 \mathrm{~mol} / \mathrm{m}^{3}$ 希硫酸中に滴下して, 脱水・脱ナトリウ 么化する方法を試みた。希硫酸と水ガラスの反応は速 く, 直ちに固化したが, 球形粒子は得られず, フロッ ク状になった。これは, 水ガラスと希硫酸との界面張 力が小さいためと考えられる。そこで, 水ガラスと界 面を形成し, 脱水作用のあるアルコールで脱水・固化 後, $500 \mathrm{~mol} / \mathrm{m}^{3}$ 希硫酸に浸し脱ナトリウムを行って 球形シリカ粒子を得ることにした。

球形を保持したまま固化するに適したアルコールを 選択するため, メタノール，エタノールおよび 2 -プ ロパノールを用いて検討した。捕集したシリカ粒子の 顕微鏡写真を Fig. 2 に示す。2-プロパノール（Fig. 2a) やエタノール (Fig. 2b) を用いると, 球形粒子が 得られなかった。一方, メタノールを用いると, 最も 球形に近い粒子が得られた (Fig. 2c)。佐藤ら”水 ガラス 3 号からシリカ粒子を作製する際， $60 \mathrm{vol} . \%$ エタノールを使用している。メタノールで脱水・固化 した粒子は，Fig. 2cのようにほとんど同心円が観察 された。液滴表面から脱水・固化が起こり, その後内 部の水が流出するため, 中空状の粒子になるためと推 
(a)

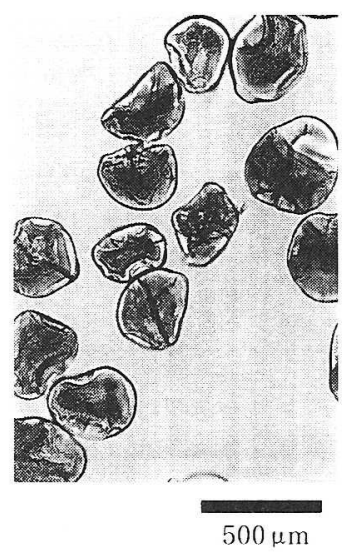

(b)

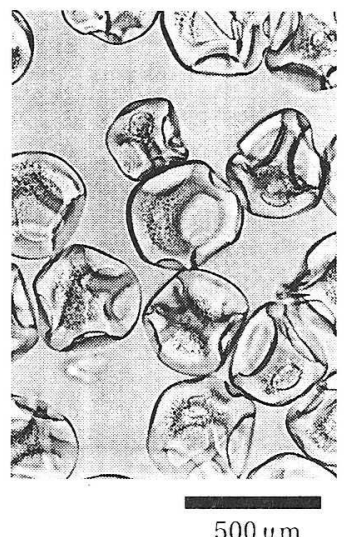

(c)

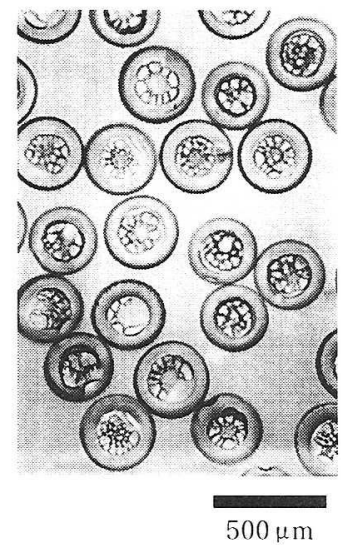

Fig. 2 Effects of particle shape on various alcohols used as collection liquids. Experimental condition is the same as the uniform cone- jet mode in Fig. 4.

(a) 2-propyl alcohol, (b) ethyl alcohol, (c) methyl alcohol

定される。2-プロパノールの場合は，写真から粒子 が中実状態と見て取れる。すなわち, 水の流出が遅く 固化が穏やかに起こると, 液滴形状が保てないが, 空 孔のない粒子ができ, 固化速度が速いと, 中空の球形 シリカ粒子が得られると考えられる。しかし，中空粒 子の場合, 内部水の流出時に, 粒子を破壊する場合も あり，適切な捕集液の選択にはさらに検討する必要が あると考えられる。

\section{2 印加電圧の影響}

対向電極板を接地し，ノズルに正の高電圧を印加し て作製したシリカ粒子の平均体積径と印加電圧の関係 を Fig. 3 に示す。印加電厈が $4.6 \mathrm{kV}$ までの領域 A は, 印加電压と共に滴下液滴径が次第に小さくなる静電滴 下状態である。 $4.6 \mathrm{kV}$ で急に小さな液滴が発生する 均一微粒化状態に移行する（領域 B)。液滴の表面に 蓄えられた電荷による静電気力が, 表面張力に打ち勝 ち，大きさの揃った小さな液滴が発生する。このと き, ノズル先端の液滴が引き延ばされ， Taylor cone $^{8)}$ と呼ばれる円錐体が観察された。この均一微粒 化状態は流量が $0.13 \mathrm{ml} / \mathrm{min}$ の場合は $5.0 \mathrm{kV}$ 付近ま で続き, $0.32 \mathrm{ml} / \mathrm{min}$ と流量の大きい場合は $5.2 \mathrm{kV}$ 付近までその状態が継続した。さらに印加電圧を増加 させると, 電流量が急に多くなる放電微粒化状態（領 域C）が見られた。この状態では大きな液滴が混ざる ため，平均粒子径は若干大きくなるが，粒子径分布は 大きく広がり, 領域 $\mathrm{B}$ と領域 Cの相違は明瞭である。 両領域の粒子径分布を Fig. 4に, 顕微鏡写真をFig. 2c （領域B）とFig. 5 (領域 C) に示す。均一微粒化状態 (領域 B) である $4.8 \mathrm{kV}$ における粒子径分布は非常に

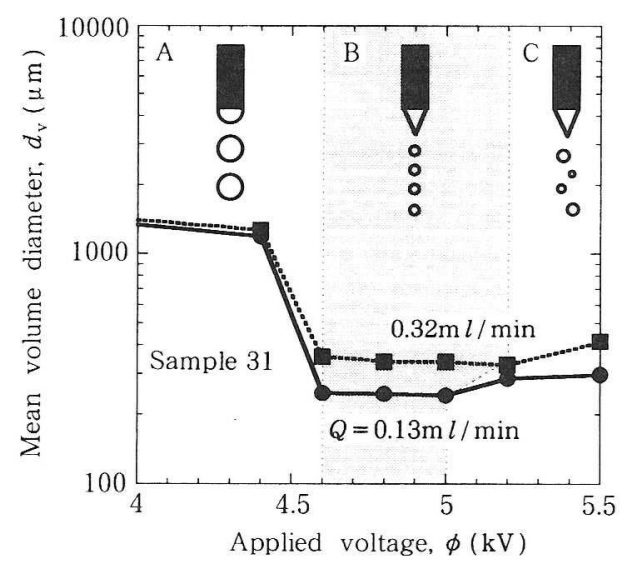

Fig. 3 Effect of applied voltage on mean volume diameter.

A : dripping mode, B : uniform cone-jet mode,

$\mathrm{C}$ : discharge mode

狭いが，放電微粒化状態（領域 C ) である $5.5 \mathrm{kV}$ の場 合は，非常に幅広い粒子径分布を持っている。本報で は大きさの揃ったシリカ粒子を得ることを目的として いるので，以下では均一微粒化状態のみについて検討 した。

次に，ノズルに印加する電圧の極性の影響を検討し た。正の電厈を印加した場合は，4.6kVから $5.2 \mathrm{kV}$ の範囲で均一微粒化状態が観測された。しかし，負の 電压を印加した場合, $4.6 \mathrm{kV}$ を印加すると, 領域 $\mathrm{A}$ の状態から直ちに領域 C の状態へと遷移し, 均一微粒

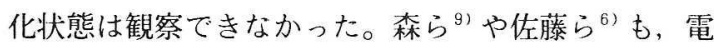
極間に正の電圧を印加したときの方が，負の電压を印 


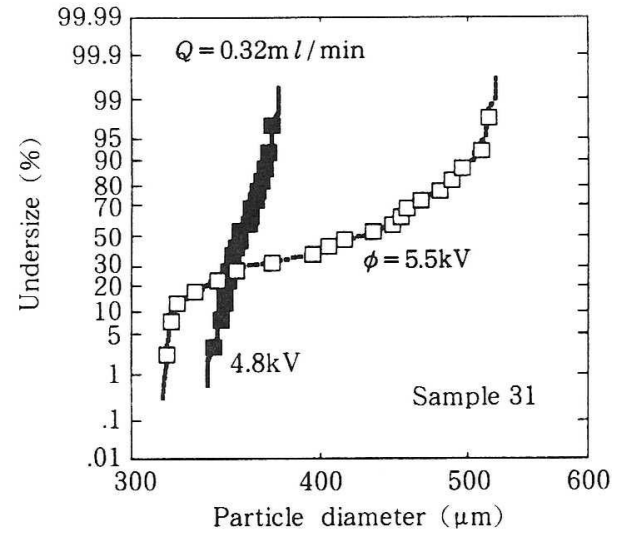

Fig. 4 Comparison of particle size distribution in uniform cone-jet mode $(4.8 \mathrm{kV})$ with that in discharge mode $(5.5 \mathrm{kV})$

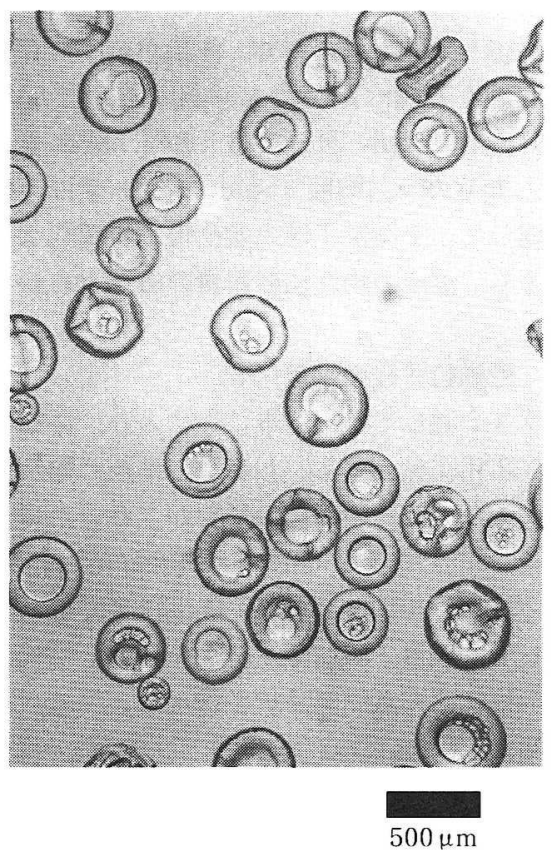

Fig. 5 Photograph of silica particles produced in discharge mode. Experimental condition is the same as Fig. 4

加した場合よりも均一微粒化状態が達成されると報告 しており，本報と同様の結果を得ている。これは，静 電微粒化に伴いノスル先端とアース電極板との間でコ ロナ放電が生じ，その正・負の放電特性が異なるため 之推定される。すなわち, 正極のコロナ放電では, 窒 素や酸素分子がイオン化しアース電極に向かうと考え られるが，負極のコロナ放電では，移動度の大きい電 子そのものが移動するため, 結果として絶縁破壊が起

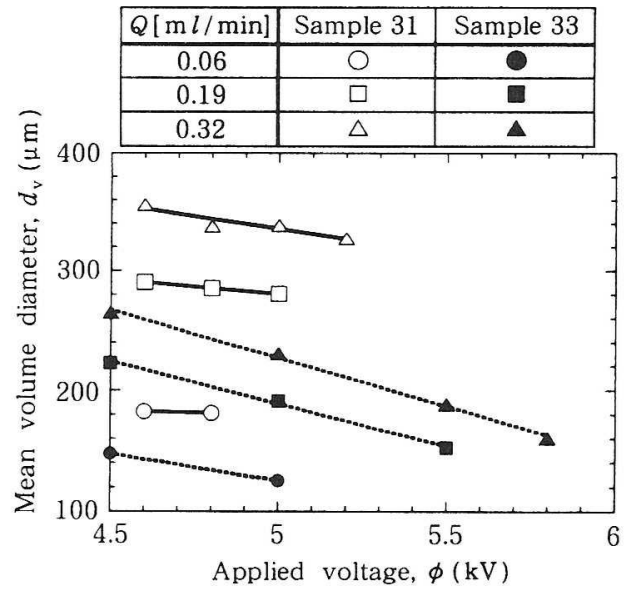

Fig. 6 Effects of applied voltage and flow rate on mean volume diameter in uniform cone-jet mode

こり，安定したコロナ放電を得にくいためであろう。 ノズル・平板間の電界強度は次式で求められる ${ }^{10}$ 。

$$
E_{0}=4 \phi /\left\{d_{0} \ln \left(8 L / d_{0}\right)\right\}
$$

Fig. 3 の電極形状条件で， $5 \mathrm{kV}$ を印加するどノズル 先端での電界強度 $E_{0}$ は, $6.7 \mathrm{MV} / \mathrm{m}$ と計算される。 空気の絶縁破壊強度 $3 \mathrm{MV} / \mathrm{m}$ を上回る大きさであ り, 負の高電圧を用いると静電微粒化は困難であると 推定される。以下では, 正の高電压を印加した結果を 示す。

印加電圧や供給流量の, シリカ粒子の平均体積径へ の影響を Fig. 6 に示す。粘性の高い Sample 31 は, 粒子径の大きいシリカ粒子が得られ, 高印加電圧で粒 子径はわずかに小さくなった。これに対し, 粘性係数 が 4 分の 1 になる Sample 33 では, 印加電圧の影響 が顕著になった。また，いずれのサンプルでも，供給 流量が小さい方が印加電压による粒子径の変化は小さ くなった。

\section{3 供給流量}

Fig. 6は供給流量の影響も示している。流量を減少 させる程, 粒子径の小さいシリカ粒子が生成した。し かし, 流量の減少とともに, 均一微粒化状態の領域が 狭くなることが判明した。 $0.06 \mathrm{ml} / \mathrm{min}$ と本報での最 小流量の条件では, Sample 31 は $4.6 \mathrm{kV}$ から $4.8 \mathrm{kV}$, Sample 33 は $4.5 \mathrm{kV}$ から $5.0 \mathrm{kV}$ の範囲となった。

印加電圧 $5 \mathrm{kV}$ におけるシリ力粒子径の分布を Fig. 7 に示す。供給流量が大きいほど分布の幅は狭くなっ た。一方, 供給流量が少なくなると, 平均粒子径は小 さくなるが，分布幅が広がった。これは，流量が少な 


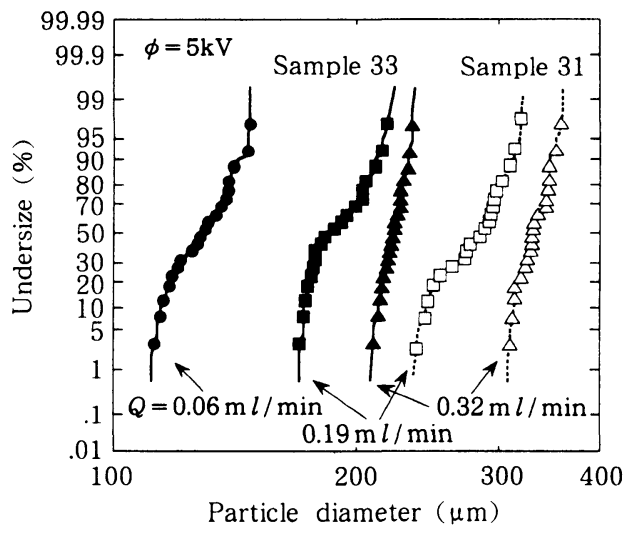

Fig. 7 Particle size distributions in uniform cone-jet mode with applied voltage of $5 \mathrm{kV}$.

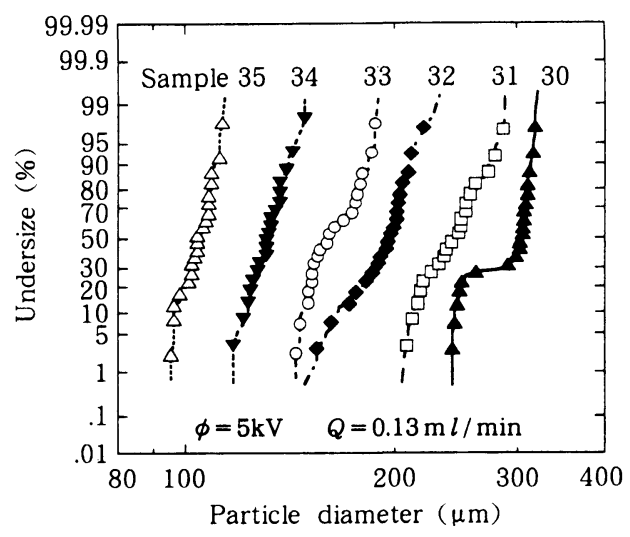

Fig. 8 Particle size distributions of various samples with applied voltage of $5 \mathrm{kV}$ and flow rate of $0.13 \mathrm{ml} / \mathrm{min}$

くなると流量制御が難しくなり，わずかな流量変化も 微粒化現象に大きく寄与してしまうためと考えられ る。

\section{4 純水の添加}

水ガラスと純水の混合比を変えた水溶液からシリカ 粒子を作製した結果を Fig. 8に示す。印加電圧 $5 \mathrm{kV}$ ， 供給流量 $0.13 \mathrm{ml} / \mathrm{min}$ とした場合である。水ガラスの みの溶液（Sample 30）では，2峰性の分布が得られ た。水の添加量が増すにつれて平均体積径は小さくな り，分布も鋭くなった。粒子径の小さいシリカ粒子を 得るには，流量を減少させることもひとつの方法であ るが，水を添加して粘度を低くした水ガラスを使用す ることが有効である。

含水量が多いと, 脱水時に液滴の収縮割合が増加す ると予想される。微粒化滴を直接シリコンオイルで捕

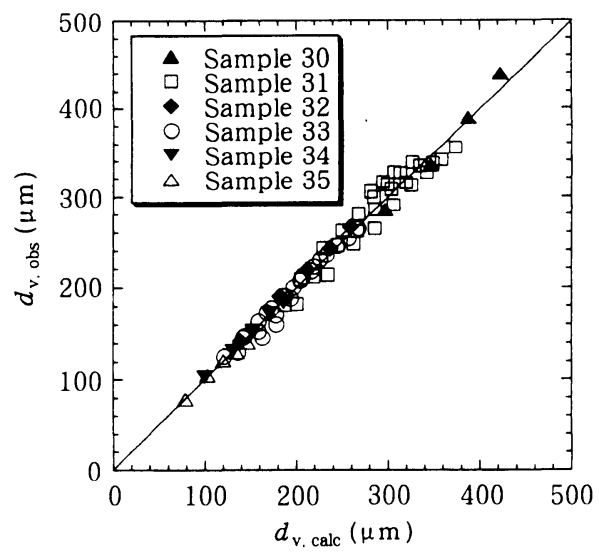

Fig. 9 Dimensionless correlation of mean volume diameter of silica particles produced under conditions in this study

集する実験と比較することで, 液滴が粒子に変化する ときの収縮率を調べた。純水を $10 \mathrm{vol} . \%$ 添加した水 ガラス溶液 (Sample 31) では $5.8 \%$ ，純水を $30 \mathrm{vol}$. $\%$ 添加した水ガラス溶液 (Sample 33) では $7.8 \%$ 直 径が収縮した。平均粒子径の変化はこの変化よりはる かに大きく，溶液の物性値の影響の方が大きいことが 分った。

\section{5 生成粒子径の推定}

水ガラスを純水で希釈することにより, 微粒化現象 の大幅な変化が見られた。しかし, 溶液の物性が同時 に変化するため, どの物性の影響が大きいかは不明で ある。そこで, 流量が $0.06 \sim 0.32 \mathrm{ml} / \mathrm{min}$, 印加電 压 $4.5 \sim 5.8 \mathrm{kV}$ の条件で均一微粒化状態であったデー 夕に対して, 流量, 印加電圧, 表面張力, 粘性係数, および導電率の多重回帰分析を行ったところ, 次のよ うな相関式を得た。

$$
d_{\mathrm{v}}=5.06 \times 10^{4} \phi^{-1.56} Q^{0.383} \gamma^{0.861} \eta^{0.313} \kappa^{2.29}
$$

この式から求めた平均体積径 $d_{\mathrm{v}, \text { calc }}$ と実測值 $d_{\mathrm{v}, \text { obs }}$ と の関係を Fig.9に示す。重相関係数は 0.986 と高く, 回帰は有意である。粒子径は導電率の影響を最も受 け，流量や粘性係数の影響は少ないことが分かる。

森ら ${ }^{9)}$ は, 蒸留水, エタノールおよびグリセリン水 溶液を用いて相関式を求めている。また，緒方ら ${ }^{11.121}$ は蒸留水, エ夕ノール, プロパノールおよびグリセリ ン水溶液を用い, $130 \mathrm{mPa} \cdot \mathrm{s}$ までの溶液に対して相 関式を導出している。さらに, 山口ら ${ }^{13)}$ は, 塩化力 リウム水溶液, グリセリン水溶液, キシレンに流動パ ラフィンや帯電防止剂を添加した溶液を用いて，微粒 
Table 2 Power indexes of physical properties of sample solution and of operating condition in the empirical correlation for the size of particles produced by electrostatic atomization

\begin{tabular}{|c|c|c|c|c|c|}
\hline & $\begin{array}{c}\text { Flow rate } \\
Q\end{array}$ & $\begin{array}{c}\text { Applied voltage } \\
\phi\end{array}$ & $\begin{array}{c}\text { Surface tension } \\
r\end{array}$ & $\begin{array}{c}\text { Viscosity } \\
\eta\end{array}$ & $\begin{array}{c}\text { Conductivity } \\
\kappa\end{array}$ \\
\hline this study & 0.383 & -1.599 & 0.861 & 0.313 & 2.291 \\
\hline Mori $^{9)}$ & 0.43 & -0.51 & -0.022 & 0.124 & - \\
\hline Ogata ${ }^{11)}$ & 0.667 & -1.111 & 0.111 & 0.444 & -0.222 \\
\hline Ogata $^{12)}$ & 0.667 & -1.111 & 0.208 & 0.25 & -0.222 \\
\hline Yamaguchi ${ }^{13)}$ & 0.47 & -1.50 & 0.52 & 0.07 & -0.08 \\
\hline
\end{tabular}

化滴を作製し，液滴径と物性の関係をまとめている。 彼らは無次元相関式を提出しているが, 無次元量が研 究者によって異なるため直接比較できない。そこで, これまでに提出された無次元相関式と Eq. (2) とを比 較するために, 次のような簡略化を行った。

まず，本研究では 1 種類のノズルしか使用していな いので, ノズルの内径と外径の比は一定とした。次 に, 今回誘電率は測定していないが, 水が多く存在す るため, 誘電率の值はそれほど変化しないと考え, 誘 電率の寄与を一定とした。この仮定のもとで, 既報の 無次元相関式から, 物性の依存性をまとめると,

Table 2のようになった。森ら ${ }^{9)}$ は, 導電率の項を含 んでいないため，空白にしてある。いずれにせよ，既 報 4 報を含めて物性値の依存性はかなりばらついてい る。特に, 本研究の導電率の項が大きく異なってい る。この理由として, 既報における導電率は $0.2 \mathrm{~S} /$ $\mathrm{m}$ 以下であるのに対して, 本研究では $3 \sim 4 \mathrm{~S} / \mathrm{m}$ と高 い值になっているためと考えられる。また, 本研究特 有の問題として, 生成粒子の大きさとの相関を採って いることが挙げられる。すなわち, 粒子径は液滴径よ り約 5 10\% 収縮し, また, 収縮率は添加水の量に 依存する。このため, 液滴径との相関式と若干異なる ことになると考えられる。

Eq. (2) は実験式であるため, 現象を理解する上で は適切とはいえない。そこで, Eq. (2) から無次元相 関式を導くことにした。誘電率の寄与を導入するに は, 溶液の比誘電率が必要である。そこで, 水の比誘 電率で一定と仮定して, 山口ら ${ }^{13)}$ が使用した無次元量 で，無次元相関式を求めると次式となった。

$$
\begin{aligned}
\frac{d_{\mathrm{v}}}{d_{0}}= & 3.83 \times 10^{-9}\left(\frac{\varepsilon_{0} E_{0} d_{0}}{\gamma}\right)^{-0.917}\left(\frac{\rho u^{2} d_{0}}{\gamma}\right)^{0.65} \\
& \times\left(\frac{\eta u}{\gamma}\right)^{0.382}\left(\frac{\varepsilon_{\mathrm{f}} \varepsilon_{0} u}{\kappa d_{0}}\right)^{-1.3}
\end{aligned}
$$

重相関係数は 0.977 と若干悪くなった。山口ら ${ }^{13)}$ の無
次元量の範囲と比較すると, 前述のように導電率の範 囲が大きく異なるため, 最後の無次元量の範囲が異な る。このため, この無次元量の指数伹が異なる。さら に, 流速 $u$ の依存性を合わせるために, $u$ を含む無次 元量の指数值も異なった。このことから, 静電微粒化 液滴径を推算する一般式を得るには, 物性の異なる データのさらなる蓄積が必要と思われる。

\section{4. 結言}

高導電率かつ高粘性係数の水ガラスに純水を添加す ることで, 溶液物性を変えて静電微粒化現象を調へた ところ, 次のような結論を得た。

1 ) 印加電圧を増加させると, 静電滴下状態, 均一微 粒化状態, 放電微粒化状態と変化した。大きさの揃 った液滴が得られるのは, 均一微粒化状態であっ た。

2 ）ノズルに印加する直流高電圧の極性を正にする と, 均一微粒化状態が観察されたが, 負にすると, 滴下微粒化状態から放電微粒化状態一之遷移し, 均 一微粒化状態が観察されなかった。

3 ）印加電圧を上げると, ノズル先端での電界強度が 増加し, 液滴放出頻度が高くなり平均体積径が小さ くなったが，その影響は小さい。

4 ）供給流量を少なくすると, 平均体積径は小さくな ったが，粒子径分布の狭いシリカ粒子を得るには流 量を多くする必要があった。

5 ) 水ガラスを水で希釈することにより, 平均体積径 が小さく, 粒子径分布幅の狭いシリカ粒子が得られ た。

6 ) 本研究結果から, 生成するシリカ粒子の平均体積 径に関して次のような実験式を得た。

$$
d_{v}=5.06 \times 10^{4} \phi^{-1.56} Q^{0.383} \gamma^{0.861} \eta^{0.313} \kappa^{2.29}
$$

[謝辞]

本研究を進めるにあたり, 鈴木油脂工業（株）の水 
口正昭氏に試料提供などの協力を頂きました。群馬 大学工学部生物化学工学科の佐藤正之教授, および (財) 地球環境産業技術研究機構の中原佳子主席研究
員には数々の助言を頂きました。また，本研究の一部 は文部省の補助による同志社大学大学院 RCAST の支 援を受けました。ここに記して感謝致します。

\section{Nomenclature}

$d_{0}$ : outer diameter of nozzle

(m) $\quad \gamma$ : surface tension of sample solution

$\left(\mathrm{N} \mathrm{m}^{-1}\right)$

$d_{\mathrm{v}}$ : mean volume diameter of silica particle

(m)

$E_{0}$ : electric field strength of nozzle tip, defined in

$$
\text { Eq. (1) }
$$

$L$ : electrode gap

$\left(\mathrm{V} \mathrm{m}^{-1}\right)$

$(\mathrm{m})$

$Q$ : volumetric flow rate of sample solution $\left(\mathrm{m}^{3} \mathrm{~s}^{-1}\right)$

$u$ : linear velocity of sample solution through nozzle

\section{$\varepsilon_{0}:$ permittivity of vacuum}

$\varepsilon_{\mathrm{f}}$ : dielectric constant of sample solution

$\eta$ : viscosity of sample solution

$\kappa$ : electrical conductivity of sample solution $\left(\mathrm{S} \mathrm{m}^{-1}\right)$

$\rho$ : density of sample solution

$\phi$ : applied voltage
$\left(\mathrm{F} \mathrm{m}^{-1}\right)$

$\left(\mathrm{F} \mathrm{m}^{-1}\right)$

$(\mathrm{Pa} \cdot \mathrm{s})$

$\left(\mathrm{kg} \mathrm{m}^{-3}\right)$

(V)

$\left(\mathrm{m} \mathrm{s}^{-1}\right)$

\section{References}

1) Cloupeau, M. and B. Prunet-Foch : "Electrostatic spraying of liquids: Main functioning modes", $J$. Electrost., 25, 165-184 (1990)

2 ) Sato, M. : "Production of uniformly sized droplets by means of electrostaitc methods", J. Soc. Powder Technol., Japan, 29, 376-383 (1992)

3 ) Watanabe, H., T. Matsuyama and H. Yamamoto: "The formation of an immobilized enzyme particle by electrostatic atomization and its performance", ibid., 34, 679-683 (1997)

4 ) Nakahara, Y. and K. Miyata: "Preparation of spherical fine particles by interfacial reaction", Kagaku Kogaku, 46, 541-546 (1982)

5 ) Nakashima, T. and M. Shimizu : "Preparation of monodispersed $\mathrm{O} / \mathrm{W}$ emulsion by porous glass membrane”, Kagaku Kogaku Ronbunshu, 19, 984-990 (1993)

6 ) Sato, M. et al. : "Production of uniformly sized silica particles with a wide controllable diameter range", Proc. Inst. Electrostst. Japan, 20, $294-300$ (1996)

7 ) Sato, M., H. Takahashi, M. Awazu and T. Ohshima: "Production of ultra-uniformly-sized silica particles by applying ac superimposed on dc voltage", $J$. Electrost., 46, 171-176 (1999)

8 ) Taylor, G.: "Disintegration of water drops in a electric field”, Proc. R. Soc. London, A280, 383-397 (1964)

9 ) Mori, Y., K. Hijikata and T. Nagasaki : "Fundamental study on electrostatic atomization", Nippon Kikai Gakkai Ronbunshu, B-hen, 47, 1881-1890 (1981)

10) The Institute of Electrostatics ed. : "Handbook of Electrostatics”, p. 172, Ohm Sha (1983)

11) Ogata, S., T. Hatae, K. Shoguchi and H. Shinohara : "The dimensionless correlation of mean particle diameter in electrostatic atomization”, Kagaku Kogaku Ronbunshu, 3, 132-136 (1977)

12) Ogata, S., K. Shoguchi, T. Hatae and H. Shinohara: "Average sizes of droplets electrostatically sprayed", ibid., 4, 656-658 (1978)

13) Yamaguchi, M., A. Matsui, H. Murakami and T. Katayama: "Formation of uniformly sized droplets of Newtonian liquids in a dc electric field", ibid., 21, 357-364 (1995) 